Vol. 1, No. 1, Juni 2020

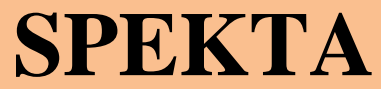

Jurnal Pengabdian Kepada Masyarakat : Teknologi dan Aplikasi

Journal homepage :

http://journal2.uad.ac.id/index.php/spekta

\title{
PENGELOLAAN KAIN TENUN SONGKET KHAS PALEMBANG DI DESA PEDU KABUPATEN JEJAWI KECAMATAN OGAN KOMERING ILIR (OKI)
}

\author{
Hidayat $^{1{ }^{1 *}, \text { Gunadi }^{1}, \text { Lazi Arlangga }^{2}, \text { Firda Yulianti }^{2}}$ \\ ${ }^{1}$ Manajemen Pendidikan Islam, UIN Raden Fatah Palembang, Jl. Prof. K.H. Zaenal Abidin Fikri Kota Palembang, \\ Sumatera Selatan, Indonesia \\ ${ }^{2}$ Bimbingan Penyuluhan Islam, UIN Raden Fatah Palembang, Jl. Prof. K.H. Zaenal Abidin Fikri Kota Palembang, \\ Sumatera Selatan, Indonesia
}

\begin{tabular}{l}
\hline INFO ARTIKEL \\
\hline Riwayat artikel : \\
Diterima : Mei 2020 \\
Direvisi : Juni 2020 \\
Disetujui : Juni 2020 \\
\hline
\end{tabular}

Keywords:

Management;

Songket;

Indonesia

\begin{tabular}{l}
\hline ABSTRACT \\
\hline Management in general can be said that the stages in \\
carrying out or carrying out management include: \\
planning, organizing, implementing, and controlling. \\
The method of implementation is a general strategy \\
adopted in the collection and analysis of data needed to \\
answer the problem being investigated or investigated. \\
The approach used is a qualitative approach with a \\
descriptive method, which provides a great opportunity \\
for researchers to describe field findings in Pedu Village. \\
Type of qualitative research. Data collection techniques, \\
as follows: observation, documentation, interviews. The \\
results of this community service activity are Peduvillage \\
people who manage varied songket cloths, this activity is \\
an effort of craftsmen to increase the attractiveness of \\
buyers by selling songket cloth at low prices but not at a \\
loss and changing yarn variations and motifs used in \\
making songket. Palembang Typical Songket Woven \\
Fabric in Pedu Village, Jejawi District, Ogan Komering \\
Ili Regency (OKI) 2020, is expected to be one of the \\
efforts to empower songket cloth better in the future so \\
that it can develop rapidly
\end{tabular}

\section{PENDAHULUAN}

Bangsa Indonesia kaya akan warisan budaya yang menjadi salah satu kebanggaan bangsa dan masyarakat. Salah satu dari warisan budaya yakni keragaman kain dan tenunan tradisional (Nurmeisarah, et al., 2015). Beberapa kain dantenunan tradisional tersebut antara lain: kain Ulos dari Sumatera Utara, kain Limar dari Sumatera Selatan, kain Batik dan Lurik dari Yogyakarta, kain Gringsing dan Endek dari Bali, kain Hinggi dari Sumba, kain Sarung Ende dari Flores, kain Buna dari Timor, kain

\footnotetext{
* Corresponding author.

E-mail address: hidayat@radenfatah.ac.id

https://doi.org/10.12928/J.spekta.v1i1.2691
} 
Vol. 1, No. 1, Juni 2020

tenun Kisar dari Maluku, kain Ulap Doyo dari Kalimantan Timur, dan kain Sasirangan dari Sulawesi Selatan (Nurmeisarah, et al., 2015).

Dilihat dari berbagai tempat mulai dari arah sebelah barat hingga timur wilayah Indonesia terdapat banyak variasi atau aneka warna songket yang dilihat dari penggunaan jenis-jenis benangnya. Adanya prinsip-prinsip persamaan dalam memproses desain timbul dari benang-benang pada kain, yaitu ada yang menghiasi seluruh permukaan kain, ada yang hanya menghiasi bagian tertentu dan ada juga kombinasi dari keduanya (Lestari, et al., 2017)

Untuk membuat sebuah kain tenun maka dibutuhkan keahlian khusus dan pengelolaan yang baik, karena pengelolaan adalah seni atau proses dalam menyelesaikan sesuatu yang terkait dengan pecapaian tujuan. Dalam penyelesaian akan sesuatu tersebut, terdapat tiga faktor yang terlibat (Sule, et al., 2009 p. 6)

1. Adanya penggunaan sumber daya organisasi, baik sumber daya manusia maupun faktor-faktor produksi lainya.

2. proses yang bertahap mulai dari perencanaan, pengorganisasian, pengarahan dan pengimplementasian, hingga pengendalian dan pengawasan.

3. Adanya seni dalam penyelesaian pekerjaan.

Menenun merupakan kegiatan yang telah ada sejak lama. Kegiatan menenun menghasilkan kain-kain tradisional khas nusantara (Badriyah, 2018). Kain songket merupakan mahkota seni penenunan yang bernilai tinggi. Teknik pembuatannya memerlukan kecermatan tinggi. Benang lungsi sutera dimasukkan melalui sisir tenun dan hendle utama pada rangkaian kain yang membentuk pola simetris dan diisi oleh benang sutra dan benang emas. (Sujanem, et al., 2018).

Dengan demikian menenun kain songket merupakan seni atau karya yang dihasilkan melalui tahapan-tahapan sesuai dengan keinginan atau motif yang dikehendaki oleh pengrajin tenun songket, karena kain tenun songket memiliki makna tersendiri.

Umumnya dikenakan pada acara-acara resmi. Benang logam metalik yang tertenu berlatar kan menimbulkan efek kemilau cemerlang (Fitriana, et al., 2017). Motif kain yang sering menghiasi kain songket adalah motif bunga, ini menandakan bahwa aktivitas menenun memiliki kedekatan dengan dan untuk wanita serta mencerminkan wanita. Pada zaman dahulu songket itu mereka tenun sambil menunggu datangnya lamaran dari laki-laki (Meriyati, et al., 2019).

Dengan demikian bisa dipahami bahwa kain songket merupakan pakaian kehormatan yang disematkan dalam acara-acara sakral seperti acara pinangan bagi wanita, pernikahan dan acara-acara lainnya. Sehingga pakaian songket menjadi kebanggaan tersendiri bagi pemakainya.

Salah satu fungsi pakaian yakni untuk menonjolkan daya tariknya, maka dalam hal ini dapat dilihat pada kemewahan dan kilauan songket dari warna-warni benang yang digunakan baik itu dengan benang emas maupun dengan benang-benang hasil celupan pewarnaan dari keahlian para penenunnya (Devi, 2015). Ragam hias yang ada pada kain tenun songket merupakan perwujudan keindahan manusia dan alamnya. Terciptanya ragam hias ini dilandasi oleh pengetahuan manusia tentang lingkungannya yang dapat merangsang untuk menciptakan aneka ragam hias (Trisna, et al., 2017)

Seni kerajinan Songket adalah karya tenun yang tidak dapat dipisahkan dari Alat. Tenun Bukan Mesin (ATBM). Jenis tenunan ini selalu melalui proses pembuatan yang cukup lama, hamper lebih kurang satu bulan untuk satu kain. Sebagaimana diketahui bahwa pekerjaanmenenun ini merupakan kepandaian yang telah diwariskan 
Vol. 1, No. 1, Juni 2020

dari generasi kegenerasi secara informal.Keterampilan yang diwariskan tidak hanya menjalankan alat tenun tetapijuga penerapan motif-motif yang telah ada sebelumnya. Motif-motif ini mengandung arti simbolis dalam kehidupan dan hubungannya dengan lingkungan hidup sehari-hari. Motivasi bertenun saatini bukan hanya sebagai ekspresi seni tetapi lebih cenderung berorientasi ke pasar. (Viatra, et al., 2014).

Setiap daerah penghasil kain tenun songket memiliki ciri khas khususnya pada pembuatan dan motif kain yang dihasilkan. Ciri khas ini menjadi identitas budaya dari tiap-tiap daerah penghasil kain tenun songket ini (Suleman, et al., 2019). Tenun songket dalam perkembangannya saat ini banyak menggunakan warna-warna yang cerah hal ini dikarena kan mengikuti jaman dan tren agar kain tenun songket tetap dapat dinikmati (Fitriana, et al., 2017).

Kain songket khas Palembang merupakan salah satu warisan budaya yang indah sejak jaman Sriwijaya, industri kerajinan kain songket Palembang banyak tersebar diwilayah kota Palembang. (Waluyati, et al., 2016). Songket masa kini telah mengalami perkembangan, terutama terjadi pergeseran nilai pada penggunaannya. Kini songket Palembang dapat dipakai oleh siapa saja yang mampu memilikinya karena sudah tidak ada aturan ketat sejak kedatangan Belanda ke Palembang dan menghapus Kesultanan tahun 1823 (Salim, 2016)

Pengelolan tenun kain songket khas Palembang di Desa Pedu ini masih sangat minim sekali, terutama dalam segi pemberdayaan pengrajin kain songketnya. Maka sangat perlu untuk melakukan kegiatan pengabdian masyarakat secara berkesinambungan, hal ini bertujuan untuk membantu masyarakat dan memberikan solusi bagi perkembangan dalam pengelolaan kain tenun songket di desa Pedu. Selain itu juga hasil wawancara dengan ibu pengrajin songket mengatakan bahwa sebelum-sebelumnya masyarakat desa Pedu rata-rata pengrajin songket akan tetapi karena penghasilannya yang di dapatkan tidak menentu tergantung pemesanan, sehingga banyak yang berhenti. Berdasarkan kondisi yang nyata di atas maka artikel ini akan membahas tentang Pengelolaan Kain Tenun Songket Khas Palembang di Desa Pedu Kabupaten Jejawi Kecamatan Ogan Komering Ilir (OKI)

\section{METODE PELAKSANAAN}

Metode penelitian menggunakan pendekatan kualitatif (Qualitative Research) adalah suatu penelitian yang ditunjukkan untuk mendeskripsikan dan menganalisis fenomena, peristiwa, aktivitas sosial, sikap, kepercayaan, persepsi pemikiran orang secara individual maupun kelompok (Sukmadinata, et al., 2013 p. 94). Adapun Teknik pengumpulan data, sebagai berikut: observasi, dokumentasi, wawancara.

Lokasi pelaksanaan Kegiatan pengabdian masyarakat terintegrasi kegiatan KKN, dilaksanakan di Desa Pedu Kec. Jejawi Kab. OKI. Waktu KegiatanKegiatan pengabdian masyarakat terintegrasi kegiatan KKN akan dilaksanakan pada hari Jum'at tanggal 31 Januari 2020

\section{HASIL DAN PEMBAHASAN}

\section{A. Pengelolaan Kain Songket Khas Palembang Di Desa Pedu, Kecamatan Jejawi, Kabupaten Ogan Komering Ilir}

Berdasarkan hasil wawancara dan pengamatan yang dilakukan peneliti dengan responden pengerajin tenun songket khas Palembang di Desa Pedu, Kecamatan Jejawi, Kabupaten Ogan Komering Ilir. 
Vol. 1, No. 1, Juni 2020

a. Perencanaan Pengelolaan Tenun Songket Khas Palembang Di Desa Pedu, Kecamatan Jejawi, Kabupaten Ogan Komering Ilir

Perencanaan pada hakikatnya adalah proses pengambilan keputusan atas sejumlah alternatif (pilihan) mengenai sasaran dan cara-cara yang akan dilaksanakan di masa yang akan datang guna tercapai tujuan yang dikehendaki serta pemantauan dan penilaiannya atas hasil pelaksanaannya, yang dilakukan secara sistematis dan berkesinambungan. Perencanaan sebagai suatu proses mempersipkan hal-hal yang akan dikerjakn pada waktu yang akan datang untuk mencapai tujuan yang telah di tetapkan. "Perencanaan dilakukan berdasarkan kebutuhan pengerajin tenun yaitu dengan memberikan pelatihan atau bahan ajar yang sesuai dengan apa yang dibutuhkan pengerajin tenun dengan langsung memberikan pelatihan atau calon pengerajin datang langsung kepada pengerajin tenun songket yang sudah profesional untuk belajar langsung bagaimana cara menenun kain songket khas palembang”. Selain itu berdasarkan hasil observasi dan pengamatan peneliti mengenai perencanaan kain tenun songket khas Palembang kepada beberapa pengrajin di dapat penjelasan mengenai pengelolaan tenun kain songket khas palembang. Berdasarkan hasil wawancara dengan pengrajin songket di antaranya: Ibu Jum Hen,Ibu Ronimah, Ibu Syarifah dan Ibu Sandariah. Mereka mengatakan dalam perencanaan pengelolaan kain tenun songket ini mereka terlebih dahulu belajar membuat kain tenun songket bersama keluarga mereka, seperti saudara mereka atau tetangga mereka yang bisa menenun. Setelah mereka sudah bisa menenun kain songket, mereka langsung mencari agen pembuatan kain tenun yang ada di pasar 16 Palembang untuk membeli peralatan tenun dan mengambil bahan pembuatan kain songket kepada agen atau pengepul kain songket tersebut. Karena mereka tidak membeli sendiri bahan kain songket tersebut melainkan diberi oleh agen kain songket tersebut.

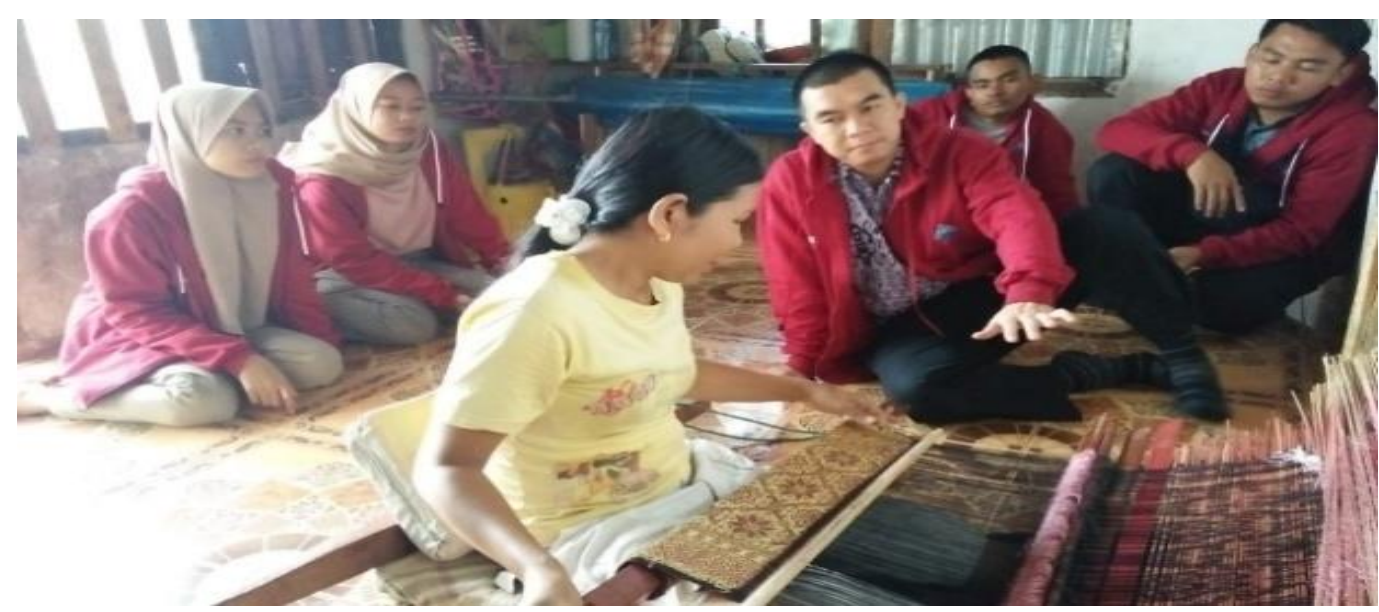

Gambar 1 Proses Pembuatan Kain Tenun Songket 


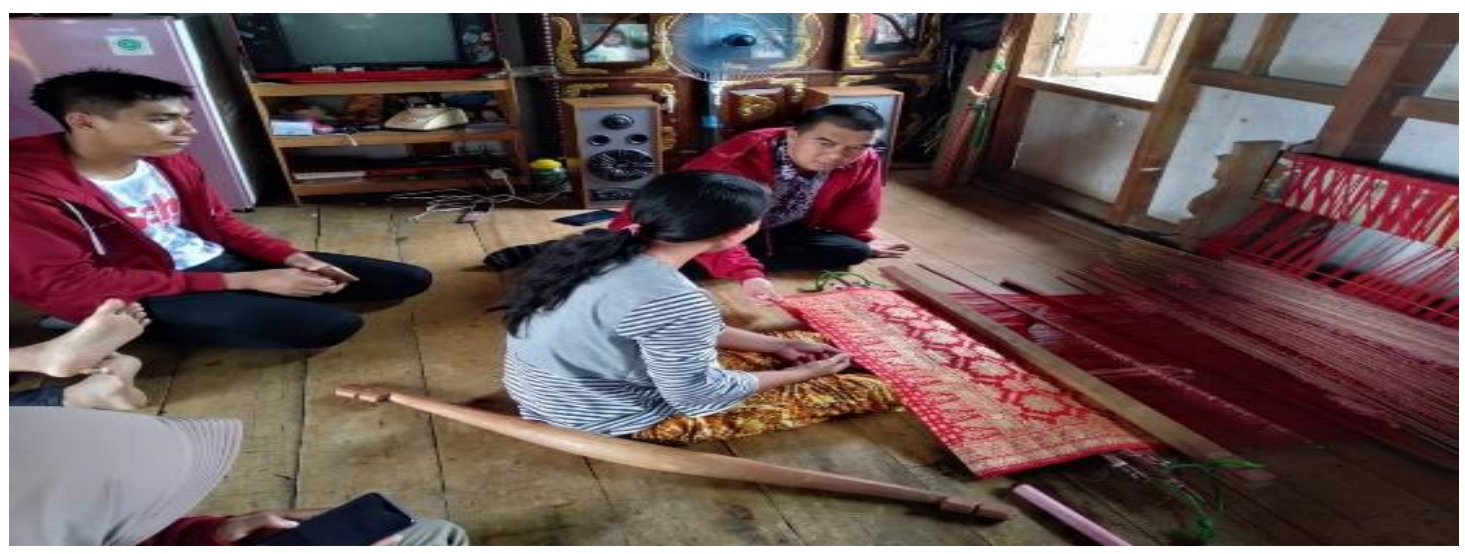

Gambar 2 Proses Pembuatan Kain Tenung Songket

b. Pengorganisasian Pengelolaan Kain Tenun Songket Khas Palembang

Pengorganisasian adalah keseluruhan proses pengelompokkan orang, alat-alat, tugas-tugas, tanggung jawab, dan wewenang sedemikian rupa sehingga tercipta suatu organisasi yang dapat digerakkan sebagai suatu kesatuan dalam rangka mencapai tujuan yang telah ditentukan. Sehingga pengorganisasian adalah penyusunan dan pembagian tugas kepada masing-masing anggota di dalam suatu kelompok untuk mencapai tuuan yang telah ditentuakan sebelumnya. Hasil dari pengamatan peneliti tentang pengerganisasian terdapat beberapa pembagian dalam proses pembuatan kain tenun songket tersebut diantaranya dalam hal fungsi masing-masing peralatan tenun diantanya pelipiran (pembatas benang atas dan benang bawah), beliro (untuk memadatkan benang-benang yang sudah disusun), apet (sebagai tempat kain jadi yang sudah di tenun), por (untuk menopang badan bagian belakang pengerajin), gon pocok (pembatas benang atas), gon bawah(pembatas benang bawah), sisir (merapikan benang), lidi (pembatas antara benang satu dengan yang lainnya), dan jiplakan kembang (sebagai pola dalam membentuk pola kembang pada kain songket).

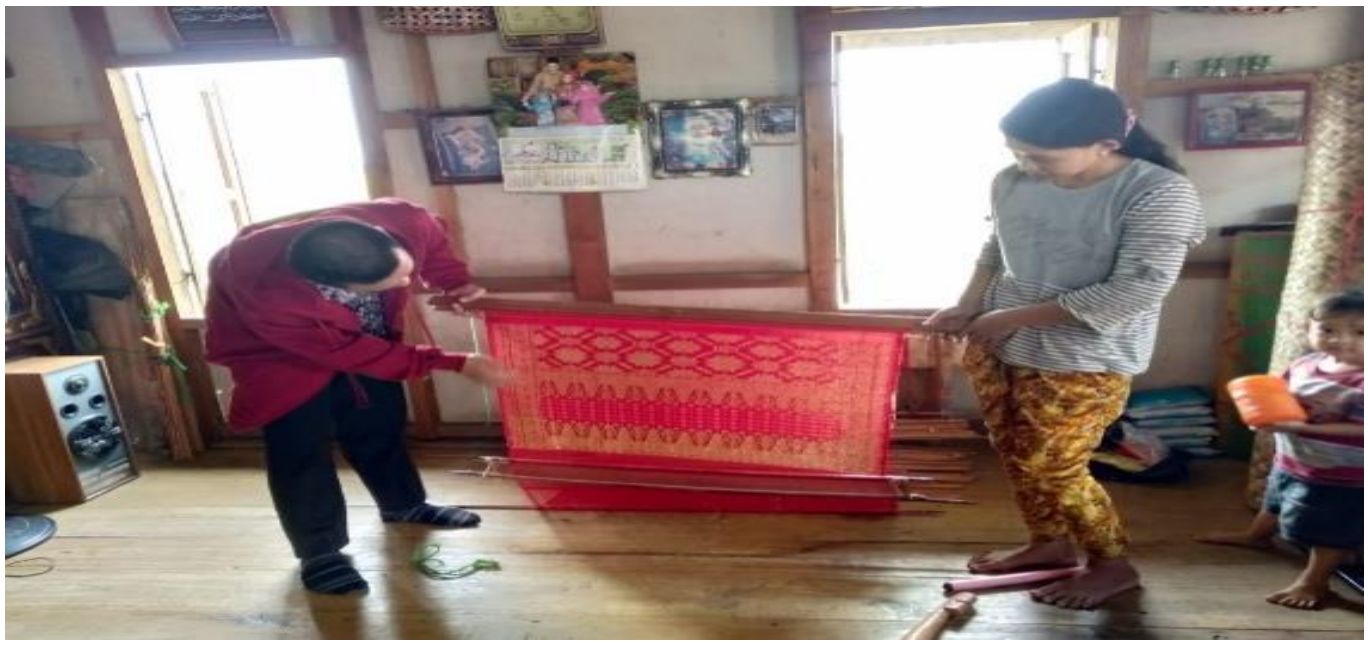

Gambar 3 Hasil Kain Tenun Songket Motif Mawar 
SPEKTA

Jurnal Pengabdian Kepada Masyarakat : Teknologi dan Aplikasi

Vol. 1, No. 1, Juni 2020

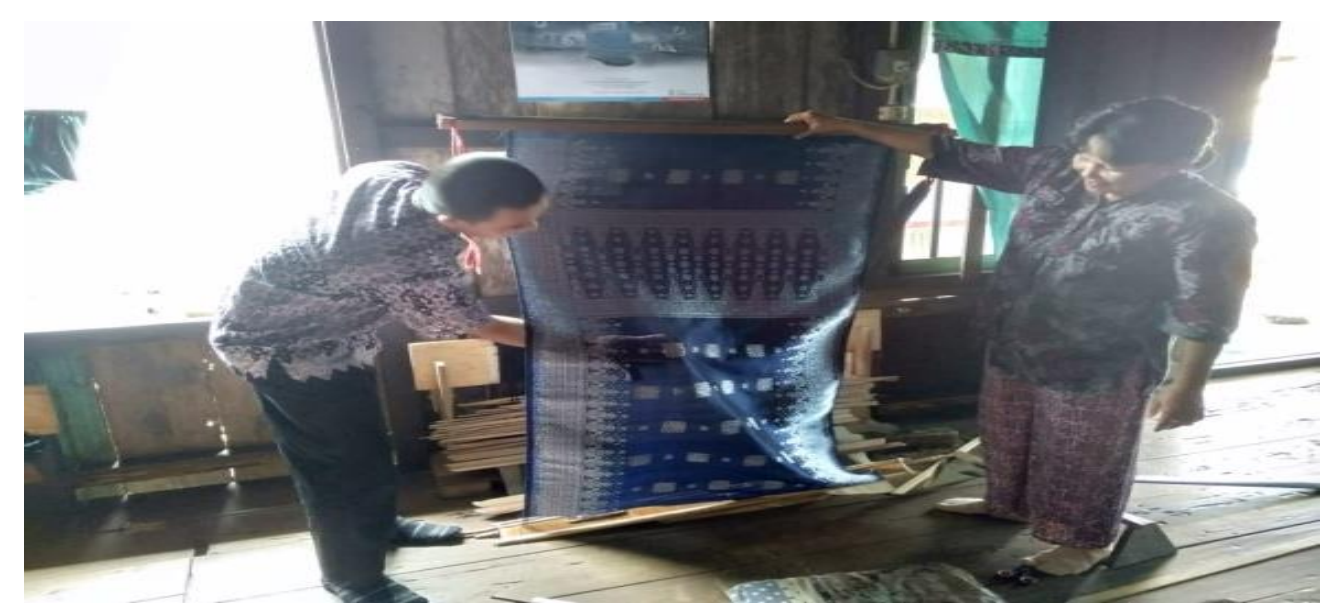

Gambar 4 Hasil Kain Tenun Songket Motif Silver

c. Pelaksanaan pengelolaan kain tenun songket khas palembang

Pelaksanaan merupakan suatu tindakan yang mengusahakan atas perencanaan dan pengerganisasi yang sebelumnya telah dilakukan. Berdasarkan hasil pengamatan peneliti terhadap responden penelitian mengenai pelaksanaan pengelolaan kain tenun songket ini yaitu pengerajin dalam pelaksanaannya pembuatan kain tenun songket dari awal sampai dengan selesai memakan waktu lebih kurang satu bulan tergantung dari pengerjaannya, jenis kain songketnya dan peralatan yang digunakan masih menggunakan peralatan yang sederhana, apabila dikerjakan setiap hari selesainya bisa mencapai 15 hari, namun apabila dikerjakan dengan melihat keadaan atau tidak rutin biasanya akan menelan waktu cukup lama, yaitu lebih kurang satu bulan. Setelah satu setel kain tersebut selesai pengerajin langsung membawa kain songket tersebut ke pasar 16 untuk dikasihkan ke agen atau pengepul songket dan pengerajin songket mendapatkan imbalan atau upah sebesar kurang lebih Rp. 900.000 s.d 1.300.000 tergantung dari jenis kain songket dan jumlah benang yang digunakan (Mawar Merah Berantai, cantik manis) serta kerumitan dalam pembuatannya.

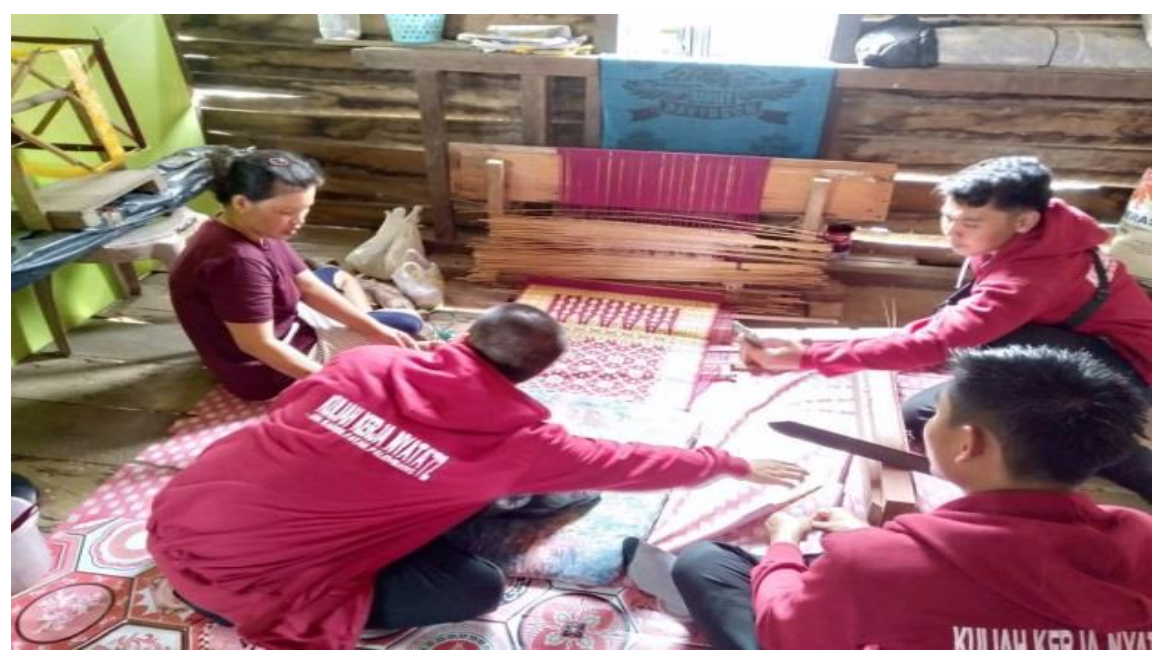

Gambar 5 Penjelasan Bahan-bahan dalam Pembuatan Kain Songket 
SPEKTA

Jurnal Pengabdian Kepada Masyarakat : Teknologi dan Aplikasi

Vol. 1, No. 1, Juni 2020

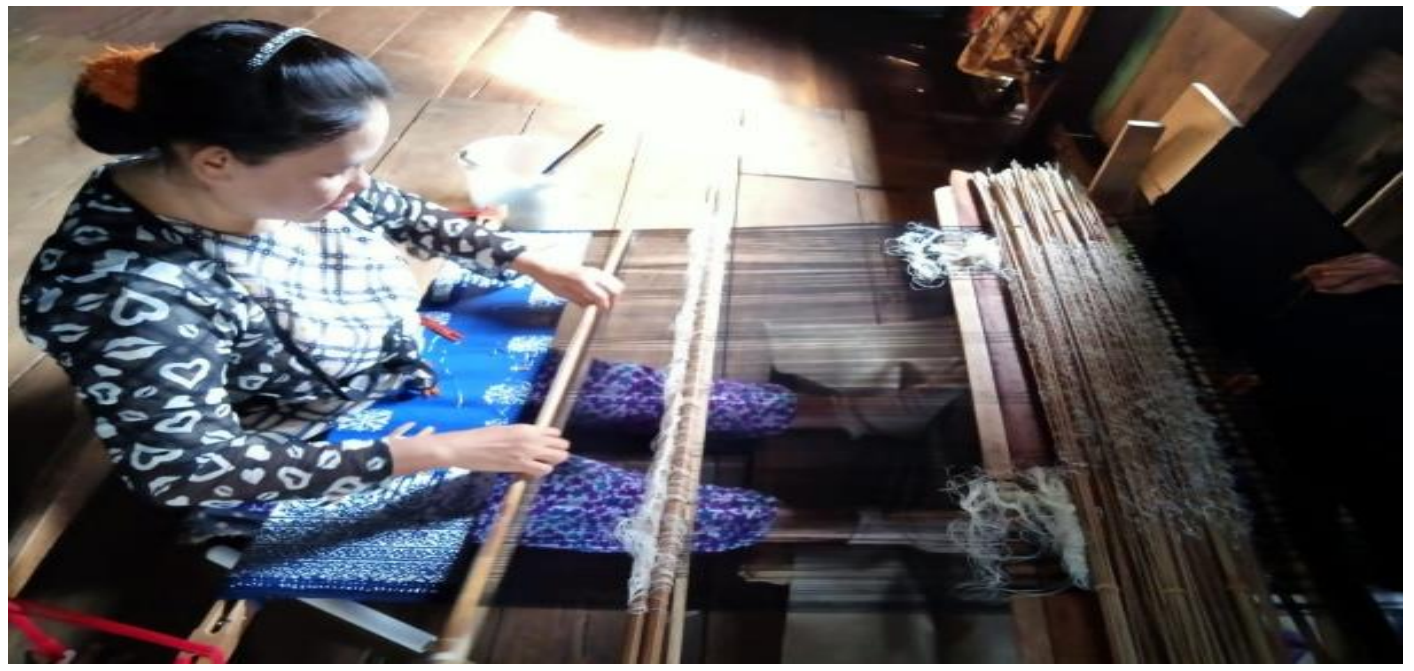

Gambar 6 Proses Pembuatan Kain Songket Secara Manual

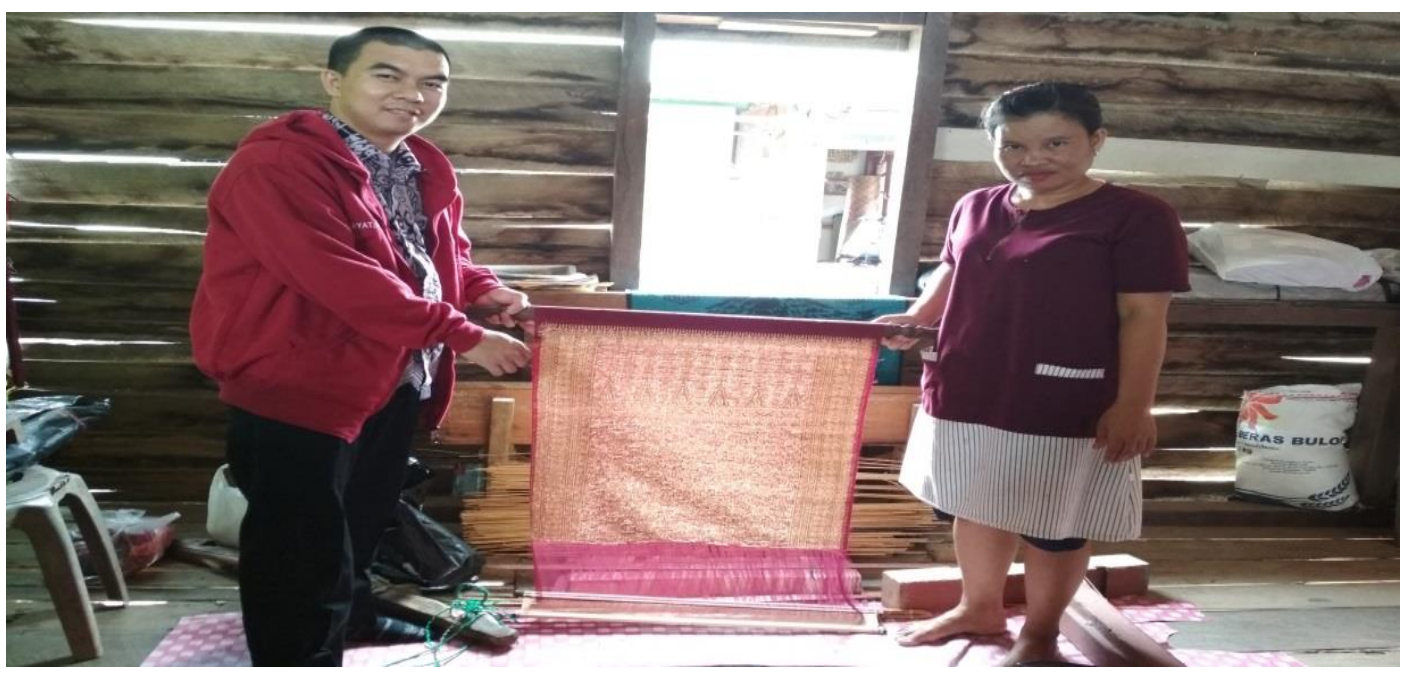

Gambar 7 Hasil Pembuatan Kain Tenun Songket

d. Evaluasi

Evaluasi adalah suatu upaya penilaian secara obyektif terhadap peraihan tujuan yang telah ditetapkan sebelumnya. Hasil evaluasi ditujukan sebagai pertimbangan dalam penentuan perencanaan dimasa mendatang. Dari hasil observasi dan wawancara bersama responden pelaksanaan dan pengolan kain tenun di Desa Pedu sudah terlaksana dengan baik namun disamping para pengrajin belum memili modal yang cukup, kurang nya perhatian dari pemerintah desa, dan dari segi sumber daya manusianya masih banyak yang kurang memiliki skill dalam menentun kain songket. Oleh karena itu perlunya perhatian dari pemerintah desa untuk memberdayakan para pengrajin tenun kain songket supaya bisa membantu perekonomian masyarakat Desa Pedu. 
SPEKTA

Jurnal Pengabdian Kepada Masyarakat : Teknologi dan Aplikasi

Vol. 1, No. 1, Juni 2020

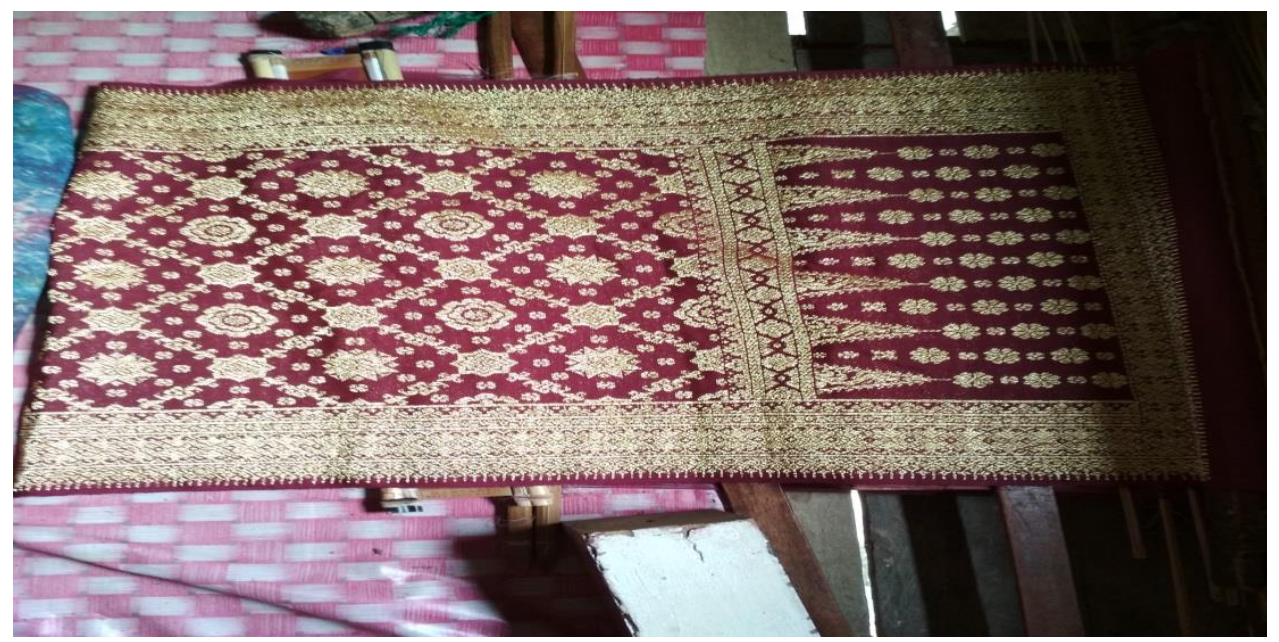

Gambar 8 Hasil pembuatan Kain tenun Songket

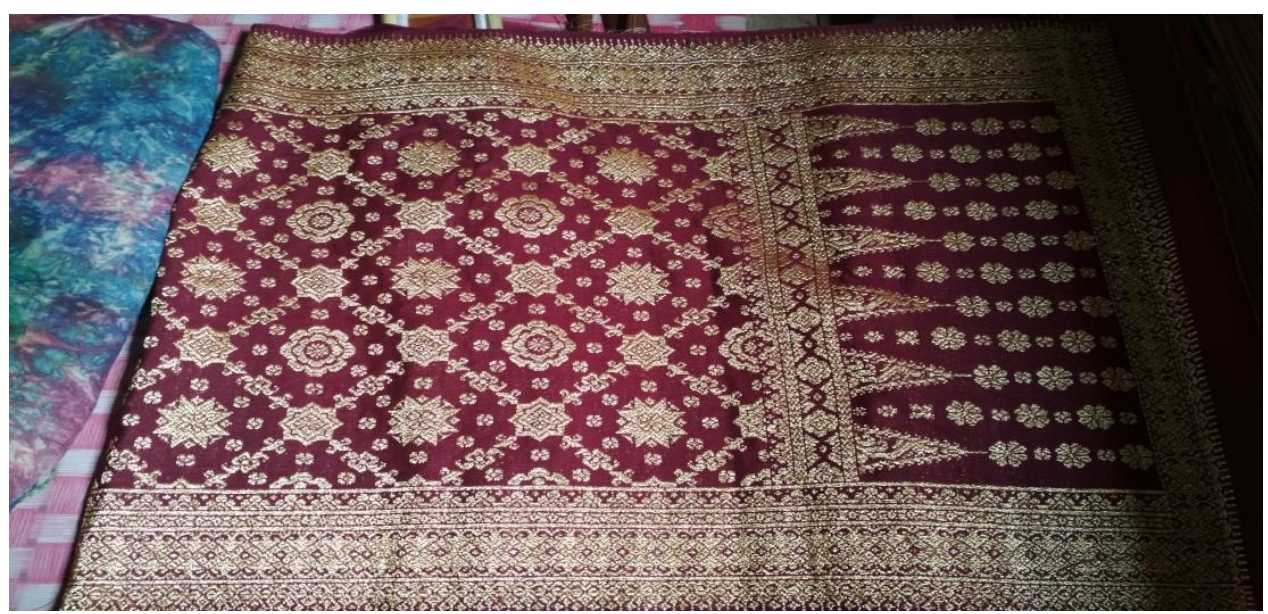

Gambar 9 Hasil Pembuatan Kain Tenun Songket Khas Palembang

\section{B. Faktor Penghambat Dalam Pengelolaan Kain Tenun Songket Khas Palembang Di Desa Pedu}

Berdasarkan hasil wawancara peneliti dengan pengerajin songket, di dapat beberapa kendala di dalam pembuatan kain songket diantaranya:

1. Faktor Cuaca

Cuaca sering kali mempengaruhi pengerajin kain songket dalam memproduksi kain songket, apabila cuaca lagi hujan atau dingin maka pengerajin songket tidak dapat memproduksi atau membuat songket di karenakan benang-benang bahan pembuatan kain songket akan lengket sehingga dapat menyulitkan pengerajin tersebut dalam membuat kain songket.

2. Faktor Keluarga

Seringkali faktor keluarga menjadi kendala atau hambatan pengerajin kain songket dalam membuat atau memproduksi kain songket, karena apabila pengerajin kain songket sdh berkeluarga otomatis pengerajin kain songket disibukkan dengan pekerjaan lain, atau pekerjaan rumah tangga, seperti: memasak, mencuci, bersih-bersih rumah dan mengasuh anak. Otomatis mereka 
Vol. 1, No. 1, Juni 2020

akan terganggu dalam membuat kain songket dengan adanya pekerjan-pekerjaan tersebut.

3. Faktor Akses Jalan

Akses jalan seringkali mengganggu pengerajin songket dalam memasarkan hasil produksi mereka, karena hasil produksi mereka di bawah ke palembang (pasar 16) untuk disetorkan kepada agen atau bos kain songket tersebut. Sedangkan jalan yang sering mereka lalui jaraknya cukup jauh apalagi ketika turun hujan maka jalan yang mereka lalui akan rusak atau becek dikarenakan ada sebagian jalan yang belum di aspal, sehingga dapat mengagnggu mereka dalam memasarkan hasil produksinya.

\section{KESIMPULAN}

Seni kerajinan tenun songket sebagai warisan budaya telah menjadibagian kehidupan dalam masyarakat Sumatera Selatan. Perkembangan danpenyebaran songket tidak hanya berkisar di kota Palembang saja, saat ini songket dapat dijumpai di daerah desa-desa termasuk Desa Pedu. Kegiatan ini ialah upaya pengrajin untuk meningkatkan daya tarik pembeli yaitu dengan menjual kain songket dengan harga rendah tetapi tidak merugi dan mengubah variasi benang dan motif yang digunakan dalam membuat songket, omzet yang didapat dari membuat songket ini ialah Rp. 1.500.000 sampai Rp. 2.000.000.

Dari kegiatan Sosialisasi Kain Tenun Songket Khas Palembang di Desa Pedu Kecamatan Jejawi Kabupaten Ogan Komering Ili (OKI) Tahun 2020, diharapkan menjadi salah satu upaya pemberdayaan kain songket yang lebih baik kedepannya sehingga dapat berkembang dengan pesat hingga ke pasar-pasar nasional dan saya ucapkan terimakasih kepada para peserta yang telah berpartisipasi dalam kegiatan ini.

Peneliti merekomendasikan kedepannya diharapkan pemerintah dapat mempromosikan tenun songket yang dihasilkan pengrajin kecil di Desa-desa yang ada di Palembang, dengan demikian para pengrajin dapat lebih giat memproduksi. Selain itu diharapkan pemerintah dapat memberikan penyuluhan dan pelatihan bagi para pengrajin agar pengrajin bisa dibina.

\section{DAFTAR PUSTAKA}

Badriyah Siti Lurik Pada Desain Interior Antara Inovasi Dan Aplikasi [Journal] // Jurnal Imaji. - 2018. - p. 92.

Devi Silvia Sejarah dan Nilai Songket Pandai Sikek [Journal] // Jurnal Ilmu Sosial Mamangan. - 2015. - p. 19.

Emzir Metodologi Penelitian Pendidikan, Kuantitatif dan Kualitatif [Book]. - Jakarta : Raja Grafindo Persada, 2013.

Fitriana Nina, Sianipar Firdaus and Resti Dian Triana Pengaruh Perkembangan Produk Kain Tenun Songket Lokal dan Kreativitas Pengrajin Terhadap Minat Masyarakat Kota Palembang [Journal] // Jurnal Kompetitif. - 2017. - p. 124.

Lestari Sasya and Riyanti Menul Teguh Kajian Motif Tenun Songket Melayu Siak Tradisional Khas Riau [Journal] // Dimensi DKV. - 2017. - p. 37.

Meriyati, Salim Amir and Sahroni Abdullah Minat Pembelian Kain Jumputan Terhadap

Kain Songket Khas Palembang (Studi Kasus: Masyarakat Kota Palembang) [Journal] // I-Economics: A Research Journal on Islamic Economics . - 2019. - p. 84. 
Vol. 1, No. 1, Juni 2020

Nurmeisarah Trisna, Sudirtha I Gede and Angendari Made Diah Tinjauan Tentang Tenun Tradisional Dusun Sade Desa Rambitan Kecamatan Pujut Kabupaten Lombok Tengah [Journal] // Pendidkan Kesejahteraan Keluarga. - 2015. - p. 1.

Salim Nadina Sukma Kain Songket Palembang dengan Penerapan Teknik Batik [Journal] // J. Vis. Art \& Design. - 2016. - p. 101.

Sujanem Rai and Sudarmawan Agus Pelatihan dan Pembinaan Kerajinan "Tenun Songket" Desa Jinengdalem [Journal] // International Journal of Community Service Learning. - 2018. - p. 108.

Sukmadinata and Syaodih Nana Metode Penelitian Pendidikan [Book]. - Bandung : PT. Remaja Rosdakarya, 2013.

Sule Erni Tisnawati and Saefullah Kurniwan Pengantar Manajemen [Book]. - Jakarta : Kencana Perdana Media Group, 2009.

Suleman Abdul Rahman, Syafii Ahmad and Hasibuan Abdurrozzaq Strategi Pengembangan Usaha Tenun Songket Motif Tradisional Singengu Textile [Journal] // Semnastek UISU. - 2019. - p. 216.

Trisna Komang Bayu, Sinarwati Ni Kadek and Sulindawati Ni Luh Gede Erni Analisis Penentuan Harga Pokok Penjualan Kain Tenun"Songket" Khas Jinengdalem Dengan Metode Activity Based Costing (ABC) (Studi Pada Usaha Tenun Songket Desa Jinengdalem, Kabupaten Buleleng, Provinsi Bali) [Journal] // e-JournalS1 Ak .2017. - p. 2.

Viatra Aji Windu and Triyanto Slamet Seni Kerajinan Songket Kampoeng Tenun di Indralaya Palembang [Journal] // Ekspresi Seni Jurnal Ilmu Pengetahuan dan Karya Seni. - 2014. - pp. 169-170.

Waluyati Sri Artati, Kurnisar and Sulkipani Analisis Upaya-upaya Pengrajin Tenun Songket dalam Mempertahankan Kelangsungan Usaha di Desa Sudimampir Kecamatan Indralaya Kabupaten Ogan Ilir [Journal] // Jurnal Profit. - 2016. - p. 68. 